\title{
THE INFLUENCE OF STUDENT ACHIEVEMENT ON TEACHER TURNOVER
}

\author{
TORBERG FALCH \\ MARTE RøNNING
}

CESIFO WORKING PAPER NO. 1469

CATEGORY 4: LABOUR MARKETS

MAY 2005

An electronic version of the paper may be downloaded

- from the SSRN website:

www.SSRN.com

- from the CESifo website:

www.CESifo.de 


\title{
THE INFLUENCE OF STUDENT ACHIEVEMENT ON TEACHER TURNOVER
}

\begin{abstract}
Evidence on teacher behavior is essential for the understanding of the performance of school systems. In this paper we utilize rich data to study the teachers' quit decision in Norway. We distinguish between decisions to move between public schools within school districts, to another school district in the same labor market region, across labor market regions, and whether to leave public schools. The results indicate that the quit propensity to all four destinations is negatively related to student performance. The result is qualitatively independent of whether student performance is measured by exam results or teacher graduation.
\end{abstract}

JEL Code: H42, I29, J44.

Keywords: teacher turnover, student achievement, family status, non-pecuniary factors.

Torberg Falch Department of Economics, Dragvoll Norwegian University of Science and

Technology

7491 Trondheim

Norway

Torberg.Falch@svt.ntnu.no
Marte Rønning

Department of Economics, Dragvoll

Norwegian University of Science and

Technology

7491 Trondheim

Norway

Marte.Ronning@svt.ntnu.no

Comments from Thomas Fuchs, Bjarne Strøm, seminar participants at the Norwegian University of Science and Technology, the International Institute of Public Finance in Milan and the EEEPE workshop in Amsterdam are greatly appreciated. 


\section{Introduction}

The recent literature clearly confirms the common sense that teachers are important for student achievement, see Hanushek (2002) and Rockoff (2004). Evidence on teacher behavior and the functioning of the teacher labor market is thus essential for the understanding of school performance. Both the choices of talented people on whether to go into teaching or not, the decisions of staying or leaving teaching, and the allocation of teachers across schools are important for individual students. The occupational choices are important for the overall efficiency of the school system, while the allocation of teachers across schools is merely a distributional question. If the best teachers are matched with high performing students and the poorest teachers are matched with low performing students, the school system may boost the inequalities in society instead of contributing to equal opportunities as intended.

The outcome in the teacher labor market depends on the behavior of several actors. The decision-making of both political institutions and the schools (school boards and school principals), the power of teacher unions, and the behavior of teachers and students contribute to the final outcome. At the most basic level, teacher quality is determined by teacher supply and teacher demand as highlighted by Bonesrønning et al. (2005). Under reasonable assumptions they are able to separately identify teacher supply and demand. However, the measure of teacher quality that follows from their approach is only one aspect of a multidimensional concept. Because the overall outcome is a result of complex interactions, confining empirical analyses to specific aspects of the teacher labor market is useful to the extent that the results from such restricted studies reflect general mechanisms.

The teacher decision to stay or leave teaching at a particular school is perhaps the most studied aspect of the teacher labor market. It is attractive from an econometric point of view because at least voluntary quits must be seen as an outcome merely of decisions of individual teachers. In addition, it is reasonable to believe that schools for which teachers tend to quit are unattractive for some reason. Determinants of quit decisions are therefore likely to indicate which factors that influence the general attractiveness of schools.

The effect of student achievement on teacher behavior is of particular importance because it has implications for the equity enhancing possibilities of the school system. If teachers flee low performing schools, teacher quality is likely to be lowest for the students most in need of a good school. Hanushek et al. (2004) find that school districts serving academically disadvantaged students have difficulties retaining teachers, while Scafidi et al. (2003) find no effects of student achievement on the teachers' quit decision. In the present paper we study quit decisions at lower secondary schools in Norway. The main achievement 
data used are the results on an external exam that each student has to undertake at the end of the lower secondary school (10th grade). This is a high stake test because the results influence the choice set for upper secondary education, undertaken by above 95 percent of the students. In addition we also investigate the effect of the teacher grading of the students, which cover several subjects, but may be due to different assessments across teachers and schools.

Existing studies of teacher moves can be divided into three groups. The first group is based on survey data and consists of papers concerned with teachers leaving teaching and focus mainly on the effects of wages and family status (e.g., Murnane and Olsen, 1989, Dolton and van der Klaauw, 1995, Stinebrickner, 2001). The second group of studies focuses on teachers leaving the school district (e.g., Gritz and Theobald, 1996, Mont and Rees, 1996, Imazeki, 2002, Hanushek et al., 2004). This research indicates that school district characteristics such as class load and student composition influence the teachers' decisions. But because such studies typically are based on register data, they typically do not condition on the family status of the teachers. A small number of papers are able to distinguish between transitions within and between school districts (Greenberg and McCall, 1974, Falch and Strøm, 2005, Scafidi et al., 2003). This may be an important aspect because recent evidence indicates that the variation in teacher quality across schools within school districts may be larger than the variation between districts (Lankford et al., 2002, Bonesrønning et al., 2005).

In this paper we distinguish between moves between public schools within school districts, to a public school in another school district in the same labor market region, across labor market regions, and whether to leave public schools. The different types of moves are likely to be affected by different factors. Separating out moves within school districts, which may react stronger to student composition and student performance than other types of moves, may be more appealing in the Norwegian institutional setting than in the US institutional setting. In the US the teachers are formally linked to the school districts and can to some extent be instructed to switch schools within the school district, while in Norway the teachers are linked to the schools. The transition observed in the US may be a result of both teacher preferences and the preferences of the school district. In Norway the teachers can only be replaced against their will if there is a serious drop in the number of students at their particular schools (as a closure of the school). Thus, the transitions observed are voluntary quits with only very few exceptions.

Further, we are able to utilize extremely rich data on teachers and schools. The employer data on teachers includes information on their wage, experience, and appointment status. This data are merged with register data on family structure, as marital status and 
fertility, and school data including a variety of information of the schools and the students. The combination of very rich description of the teachers and the schools makes this data set unique. The sample is restricted to the school years 1998-99 to 2001-02 due to availability of student performance data, and we further restrict the sample to teachers with permanent appointment to focus on voluntary quits.

The next section set out a simple framework to think about how determinants of teacher quits are likely to be related to determinants of teacher quality. The data used are presented in Section 3, and the empirical results are provided in Section 4. Section 5 contains concluding remarks.

\section{Theoretical approach}

Teacher quality must at some level be related to teacher supply. If no teachers are willing to work at a school, thinking about teacher quality is meaningless. On the other hand, schools faced with an extremely high supply should obviously be able to obtain a high teacher quality. Thus, our starting point is that teacher quality is positively related to teacher supply. There exist very few empirical analyses of the labor supply faced by individual schools or firms. ${ }^{1}$ The main problem with studies of this kind is that one typically does not have good instruments for wages. Thus, it is attractive to study individual behavior because wages can more reasonable be considered as exogenous at the individual level.

For a school, changes in individual's ranking of the school compared to other potential employers may be seen as a change in the teacher supply directed towards the school. To formalize, decompose the supply $\mathrm{S}$ faced by a school into the current incumbent teachers $\mathrm{T}$, new hires $\mathrm{H}$, and teachers who want to work at the school but who are not offered a post $\mathrm{M}$. Then $\mathrm{S}=\mathrm{T}+\mathrm{H}+\mathrm{M}$. The change in teacher supply, say from the start of the previous school year $\mathrm{t}-1$ to the start of the present school year $\mathrm{t}$ can then be defined as

$\Delta \mathrm{S}=\Delta \mathrm{T}-\mathrm{H}_{\mathrm{t}-1}+\Delta \mathrm{M}+\mathrm{H}_{\mathrm{t}}=-\mathrm{q}+\mathrm{m}+\mathrm{h}$,

where $\Delta$ is a differential operator. The number of quits $\mathrm{q}=-\Delta \mathrm{T}+\mathrm{H}_{\mathrm{t}-1}$ is defined as the number of incumbent teachers the previous school year $\left(\mathrm{T}_{\mathrm{t}-1}+\mathrm{H}_{\mathrm{t}-1}\right)$ minus the number of incumbent teachers at the start of the present school year $\left(T_{t}\right) . m=\Delta M$ is the change in the potential and unrealized school-teacher matches, and $h$ is the number of new matches $\left(\mathrm{H}_{\mathrm{t}}\right)$. From (1) it follows that both analyzes of the matching of teachers and schools and the quit

\footnotetext{
${ }^{1}$ The exceptions are some studies of the labor market for nurses (Sullivan, 1989, Staiger et al., 1999.) and some studies of teacher supply (Currie, 1991, Falch, 2003, Bonesrønning et al., 2005).
} 
behavior of existing teachers may be seen as analyses related to the change in teacher supply. If the quit rate increases for some reason, hires must increase correspondingly, presumably reducing the average quality of the new matches, but certainly reducing the number of potential but unrealized matches.

School characteristics may of course have different quantitative effects on turnover decisions and matching processes. In particular, features of the first match for a newly educated teacher will influence their later turnover decisions. If attractive schools prefer teachers with high experience and good references, young teachers must start their career in less appealing schools and work their way up to more appealing schools. Then quit decisions will be more sensitive to school characteristics than the initial match. On the other hand, if all matches are based on perfect information about the teachers and the present situation at the schools, turnover will only be related to changes in school characteristics.

Analyzing the matching process is complicated by the fact that one only observes actual matches and not potential matches. ${ }^{2}$ Determinants of the quit decisions of existing teachers are therefore easier to analyze because all quits can in principle be observed. In the following, we will argue that the matching and quitting processes are likely to be influenced by the same factors. If a school turns less attractive, it will both increase the quit propensity of its initial teachers and make the school less appealing for new teachers. Teachers, like other workers, prefer more pleasant working conditions to less pleasant ones.

Let the utility of working in a particular school depends on the wage $\mathrm{W}$ and nonpecuniary rewards $N$. Then the lifetime utility from time $t$ on for teacher $i$ working in school $j$ can be written

$\mathrm{U}_{\mathrm{jt}}^{\mathrm{i}}=\mathrm{u}^{\mathrm{i}}\left(\mathrm{W}_{\mathrm{jt}}, \mathrm{N}_{\mathrm{jt}}\right)+\delta \mathrm{E}\left(\mathrm{U}_{\mathrm{jt}+1}^{\mathrm{i}}\right)$,

where $\delta$ is a discount factor and $\mathrm{E}$ is an expectational operator. School $\mathrm{j}$ is in the choice set $\mathrm{J}$, where $\mathrm{J}$ includes schools, other jobs, and being out of the labor force. Then the teacher will prefer another state if

$\mathrm{u}^{\mathrm{i}}\left(\mathrm{W}_{\mathrm{jt}}, \mathrm{N}_{\mathrm{jt}}\right)+\delta \mathrm{E}\left(\mathrm{U}_{\mathrm{jt}+1}^{\mathrm{i}}\right)<\underset{\mathrm{k} \in \mathrm{J}, \mathrm{k} \neq \mathrm{j}}{\max }\left\{\mathrm{u}^{\mathrm{i}}\left(\mathrm{W}_{\mathrm{kt}}, \mathrm{N}_{\mathrm{kt}}\right)+\delta \mathrm{E}\left(\mathrm{U}_{\mathrm{kt}+1}^{\mathrm{i}}\right)-\mathrm{c}^{\mathrm{i}}\right\}$,

where $\mathrm{c}^{\mathrm{i}}$ is the moving cost. Teacher $\mathrm{i}$ will prefer to quit school $\mathrm{j}$ if she is offered a job in $\mathrm{k}$. Assuming that $\mathrm{E}\left(\mathrm{U}_{\mathrm{jt}+1}^{\mathrm{i}}\right)=\mathrm{E}\left(\mathrm{U}_{\mathrm{kt}+1}^{\mathrm{i}}\right)$, that is, the job today do not affect the opportunities in the future, (3) can be written

\footnotetext{
${ }^{2}$ To the best of our knowledge, the only empirical study of two-sided match in the market for teachers is Boyd et al. (2003). By utilize the method of simulated moments they model the interaction between schools and teachers in a game-like fashion.
} 
$\mathrm{u}^{\mathrm{i}}\left(\mathrm{W}_{\mathrm{jt}}, \mathrm{N}_{\mathrm{jt}}\right)<\max _{\mathrm{k} \in \mathrm{J}, \mathrm{k} \neq \mathrm{j}}\left[\mathrm{u}^{\mathrm{i}}\left(\mathrm{W}_{\mathrm{kt}}, \mathrm{N}_{\mathrm{kt}}\right)-\mathrm{c}^{\mathrm{i}}\right]$

If $\mathrm{W}_{\mathrm{jt}}$ or $\mathrm{N}_{\mathrm{jt}}$ increases, there will exists fewer alternatives that yield a higher utility level than staying at school $\mathrm{j}$, which decreases the probability of being offered a job preferable to staying at school $\mathrm{j}$. When the probability that teachers at school $\mathrm{j}$ have a better alternative decreases, less teachers quits, and q decreases. For teachers not working at school $\mathrm{j}$, the rise in $\mathrm{W}_{\mathrm{j}}$ or $\mathrm{N}_{\mathrm{j}}$ increases the probability that school $\mathrm{j}$ is preferable compared to their present position, which increases $\mathrm{m}$ in (1). ${ }^{3}$ Within this set-up, each factor that makes a school more attractive will both reduce the quit propensities of incumbent teachers and increase the number of applicants to vacant teacher posts.

In the dynamic framework of Burdett (1978), with incomplete information and costly job search, the search intensity depends on the present utility level. Burdett (1978) shows that higher wages reduce the quit propensity of workers, both because the probability of being offered a higher wage than the present wage is reduced and because it is optimal to reduce the search intensity in this case. At the same time, a vacant position is more likely to be matched with a worker preferring this job over her alternatives when the wage increases because fewer will reject a job offer. Thus, a rise in the wage will both decrease the quit propensity of existing workers and increase the match propensity of new workers.

The teacher labor market is characterized by a rigid wage. In the US the wage vary very little within school districts, while in many European countries as the UK, Germany, France and Norway, there are almost no national variation in the wage. In the framework above, non-pecuniary rewards $\mathrm{N}$ then have an important impact on teachers' preference ranking of the schools. In the analysis below, we will include a range of different measures that can influence the attractiveness of the work environment at different schools. For example, it is expected to be more pleasant to teach well-performing students than poor performing students.

The family status, as for example presence of school-aged children, is likely to be important for the moving costs, in particular for moves that require a residential change. In addition, the valuation of non-pecuniary aspects may depend on teacher characteristics as indicated by the formulation above.

Besley and Ghatak $(2003,2005)$ argue that the effort agents provide in public organizations depend on their valuation of the output produced. Thus, the mission of the teachers relative to the mission of the schools, deciding teachers' valuation of the output,

\footnotetext{
${ }^{3}$ In addition, $\mathrm{m}$ will increase because a lower quit rate reduces new hires.
} 
affects the degree of effort teachers are willing to provide, and quit decisions observed is related to mismatch of teachers and schools. Within a relatively centralized public school system, we do not believe the missions of the schools vary nearly as much as the motivation of the teachers. The dedication to serve low-performing students is likely to vary across teachers to a larger extent than across schools. However, teachers leaving a school must be replaced, and systematically high hiring rates are likely to make it hard to achieve high teacher quality because, within the framework above, $\mathrm{m}$ is likely to be low. Nevertheless, when attempting to single out the quits that are important for teacher quality, it may be important to include in the model a detailed set of teacher characteristics that may account for differences in mission.

\section{Data and econometric specification}

The utilization of several data sources makes the data abounding in information about the individual teachers and schools. We use employer register data, collected by the Ministry of Labor and Government Administration, covering all Norwegian teachers in public schools. ${ }^{4}$ The data include, e.g., information on wages, experience and appointment status. These data are merged with individual information from Statistics Norway, including family characteristics as fertility and marital status, and region of birth. Further, this sample is combined with school data collected by the Ministry of Education (Grunnskolens Informasjonssystem) as well as recently available student test-scores from the Norwegian Board of Education. The achievement data available are the results at the end of the lower secondary school (10th grade) for the school years 1999-2000 to 2001-02. Finally, as remaining controls, we use regional data from the Norwegian Social Science Data Services.

Because we focus on the effect of student achievement at the end of the 10th grade, the sample is reduced to teachers working at schools including this level. About half of these schools are combined primary and lower secondary schools (1st to 10th grade), the rest is pure lower secondary schools (8th to 10th grade). Since only voluntary quits are of interest, only teachers with permanent appointments are included in the sample, excluding teachers on

\footnotetext{
${ }^{4}$ In the school year 2000-01, 1.7 percent of the students at primary and lower secondary schools were enrolled in private (mostly religious) schools. Teachers at those schools are not included in our sample.
} 
short term contracts. ${ }^{5}$ In addition, in order to avoid retirement decisions, teachers over 60 years of age are excluded from the sample.

Mobility both to a primary, lower secondary and upper secondary schools $\left(11^{\text {th }}\right.$ to $13^{\text {th }}$ grade) are identified. In the baseline empirical model we will distinguish between four types of teacher mobility: moves to another public school in the same school district, ${ }^{6}$ moves to a public school in another school district in the same labor market region, moves to a public school in another labor market region, and moves out of the public school sector. ${ }^{7}$ The comparison group is teachers that do not move at all. The local labor market regions used are defined by Statistics Norway. Based on commuting statistics, they identify 90 labor markets, covering on average 4.8 school districts. Table 1 gives a brief summary of the teachers' moving pattern.

Table 1. Teacher turnover 1998-99 to 2001-02 in percent

\begin{tabular}{lccccc}
\hline & $\mathbf{1 9 9 8 - 9 9}$ & $\mathbf{1 9 9 9 - 2 0 0 0}$ & $\mathbf{2 0 0 0 - 0 1}$ & $\mathbf{2 0 0 1 - 0 2}$ & $\mathbf{1 9 9 8 - 2 0 0 2}$ \\
\hline Do not quit at all & 89.33 & 88.95 & 90.06 & 91.16 & 89.88 \\
Moving to a school in the same school district & 3.12 & 3.18 & 2.66 & 2.41 & 2.84 \\
$\begin{array}{l}\text { Moving to a school in another school district } \\
\begin{array}{l}\text { in the same labor market region } \\
\text { Moving to a school in another labor market }\end{array}\end{array}$ & 0.67 & 0.78 & 0.56 & 0.39 & 0.60 \\
$\begin{array}{l}\text { region } \\
\text { Moving out of public schools }\end{array}$ & 5.31 & 5.50 & 5.36 & 4.95 & 5.28 \\
$\begin{array}{l}\text { Total mobility } \\
\text { Observations }\end{array}$ & 10.66 & 11.04 & 9.94 & 8.84 & 1.09 \\
\hline
\end{tabular}

On average over the school years 1998-99 to 2001-02, about 90 percent of the teachers do not quit at all. Most of the teachers that quit leave the public school sector, while moves to another school district within the same labor market region only includes 0.6 percent of the

\footnotetext{
${ }^{5}$ Teachers at schools that are not in the data the next school year (school closures) are removed from the sample. Due to increased overall teacher employment during the empirical period, there exists extremely few other cases where teachers are instructed to leave their initial school.

${ }^{6}$ In Norway, primary and lower secondary education is the responsibility of the municipalities. The municipalities are multipurpose institutions with the responsibility for care for the elderly, daycare, infrastructure, etc. Spending on primary and lower secondary education accounts for about 30 percent of total municipal spending.

${ }^{7}$ Teachers who are not in the data the next school year are defined as movers out of public schools. Teachers on paid leave (mostly maternity leave) are considered as stayers.
} 
teachers. The quit propensity increased slightly from 1998-99 to 1999-2000, and decreased markedly thereafter to 8.8 percent in the school year 2001-02.

We expect the effect of school characteristics, as for example student achievement, to be strongest for moves within school districts and smallest for moves to another school district in the same local labor market. The latter type of moves are expected to be mainly motivated by reduced commuting time, while the former types of moves to a greater extent may be due to searches for the "best" school within a reasonable commuting space.

\subsection{Baseline model}

The econometric specification relates school and teacher characteristics to teacher moving pattern. The empirical analysis is based on the traditional multinomial logistic regression model.

$$
\operatorname{Pr}\left(\text { move }_{\text {ist }}=j \mid Y\right)=\frac{e^{Y \beta_{j}}}{\sum_{h=0}^{4} e^{Y \beta_{h}}}
$$

where the dependent variable move includes the five destinations described above for teacher $i$ in school $s$ in region $r$ at time $t$. The vector of independent variables $\mathrm{Y}$ includes variables at the individual, school, and regional levels.

\section{Test scores}

Student achievement is expected to influence the teachers' required effort and their general well-being positively. Increased student achievement may make the work more pleasant, improving the non-pecuniary rewards.

At grades 8 to 10 , the students are graded by their teachers. At the end of the 10th grade, the students must undertake an external examination. Both the exam results and the grading of the teachers matter for further schooling possibilities. Although all students have the right to continue at upper secondary schools (see Falch, 2002), and above 95 percent do continue, their choice set among different schools and different study tracks depends on their achievement in lower secondary schools. In this regard, the exam is clearly a high stake test for the students. In this paper we mainly focus on the exam results because they are set by external examiners.

The curriculum consists of a lot of different subjects, some of them are compulsory while others are elective. Written examination is only undertaken in the three main subjects; 
mathematics, English and Norwegian. ${ }^{8}$ However, most commonly each student only participates in one of these exams, decided centrally shortly before the exam. Often all students at a school have their exam in the same subject. Thus, in our analysis we will use the mean performance across these subjects.

In the grading 6 is top score, while 1 is fail. The distribution of the grades in mathematics one particular school year is presented in Figure 1. The grading is reasonable normally distributed. For the other subjects, the distribution is very similar. ${ }^{9}$ Nevertheless, when calculating weighted average achievement at the schools, we use standardized results for each subject in each year (mean equal to zero and standard deviation equal to unity). ${ }^{10}$

In sensitivity analyses, we replace this achievement measure by the grading of the teachers in the same subjects. One advantage of using teacher grading is that all students are graded in all three subjects. In addition, we test the effect of the share of low-performing students, defined as the share of students with grade 1 or $2 .^{11}$

\section{Figure 1. The distribution of examination grades in mathematics in 1999-2000}

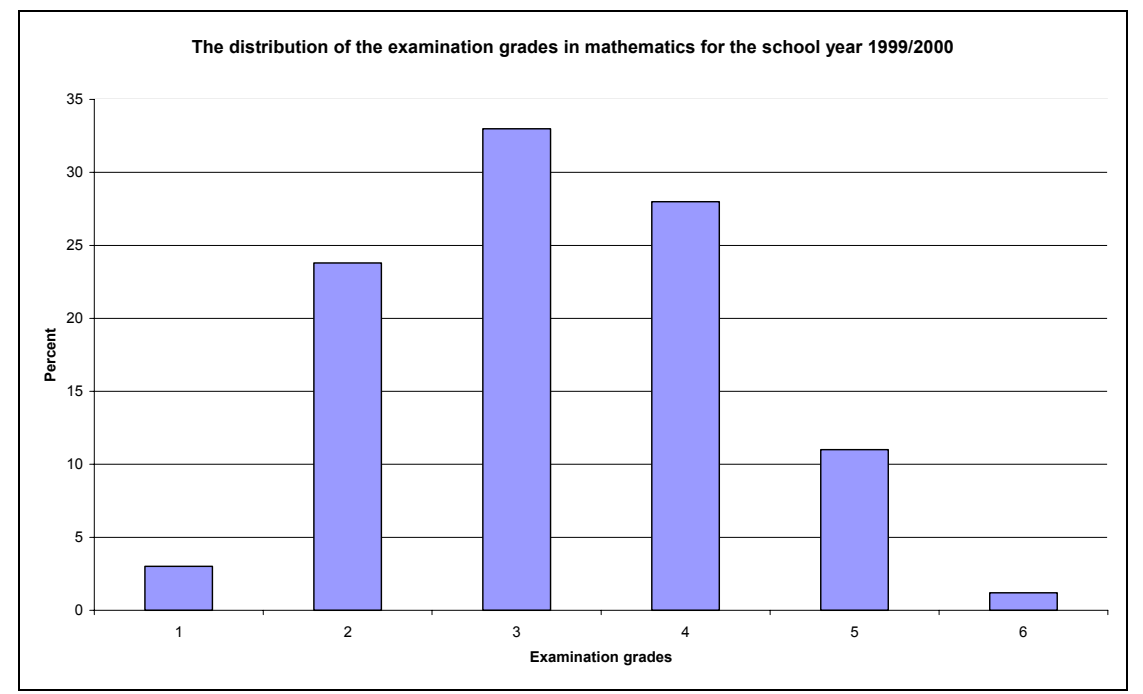

\footnotetext{
${ }^{8}$ Norwegian includes two separate exams in the two official written languages in Norway.

${ }^{9}$ For example, in the school year 2001-02, the mean result was $3.55(0.53), 3.48(0.60), 3.59(0.59)$ and 3.39 (0.70) in mathematics, English and the two exams in Norwegian, respectively. Standard deviations in parentheses.

${ }^{10}$ The correlation coefficient between average standardized achievement and the average of the exam grading (non-standardized) is 0.92 .

${ }^{11}$ The correlation coefficient between the average of the standardized exam results and the grades given by teachers is 0.54 . The correlation coefficient between the average of standardized exam results and the share of low performing students at the exam is -0.78 .
} 
The test score used in the analysis is related to the students finishing their lower secondary education. But if teachers are forward looking, they should be interested in the ability of the students at school the next school years. Current achievement of the $10^{\text {th }}$ graders may be an imprecise measure of the ability of interest for the teacher decisions, which should bias the estimate against zero as with classical measurement error. In order to shed more light on this issue, we will also present results using leaded and lagged achievement instead of current achievement.

\section{Other school characteristics}

To control for other conditions with the particular school that might influence teacher turnover we include several additional school characteristics. The main role of the school district is to decide the budgets of the schools. As a measure of the resource use we include total teacher education hours per student, which a slightly more detailed measure than the teacher-student ratio. Teacher education hours is the amount of time teachers interact with students, and is not perfectly correlated with teacher man-years because the work load varies between subjects and depends on the amount of non-teaching tasks. The common assumption is that increased resource use improves the working conditions and reduces teacher quits, although the findings in the literature are mixed (Hanushek et al., 2004, Falch and Strøm, 2005).

Student composition is characterized by measures of students with special needs and minority students. There has been increasing interest in the role of such characteristics for teachers' decision on which school to attend, see, e.g., Gritz and Theobald (1996), Scafidi et al. (2003), Hanushek et al. (2004) and Falch and Strøm (2005). Our detailed school data makes it possible to separate between quantity and severity of the student composition. As measures on quantity we include the share of students with special needs and the share of minority students. The severity of, for example, students with special needs is measured utilizing the accounting of resource use at schools. The total teaching education hours at each school consist of a baseline nationally determined minimum plus additional hours to specific purposes. ${ }^{12}$ The additional hours at least partly reflects the needs of the student population, and both the variables additional teacher education hours for student with special needs per student with special needs and additional teacher education hour for minority students per

\footnotetext{
${ }^{12}$ According to the school act, extra resources have to be allocated to students with special needs based on individual education plans to be designed in an interaction between teachers, parents, specialists on disabled students, and the local government. The amount of extra resources entitled to each student shall be determined by their needs. A similar rule is in place for minority students.
} 
minority student are included in the analysis. Information on family background of the $10^{\text {th }}$ graders is available from the school year 2001-02 only, and we utilize this information in some robustness checks.

In addition to the student body composition, we also include the share of non-certified teachers at school as a measure of the composition of the teachers. ${ }^{13}$ We expect a positive effect of this variable because teachers may prefer to work with colleagues with the same education background, but this variable may also pick up the effect of some missing variables on school attractiveness.

A teacher may also regard the school size when she considers the quit decision. Because of large variation in the Norwegian settlement pattern there is a huge difference between the smallest and largest schools. We include the logarithm of the number of pupils at level and squared form in the model to capture nonlinear effects. In addition, whether there are students at the primary level at school (combined schools) is included as a control variable in the model.

Table 2 presents correlation coefficients between average student achievement and some of the school characteristics. The correlations between the test scores and the share of minority students and the share students with special needs are negative. The variables capturing the severity of the student composition, school size and whether there exist classes at the primary level at the school seems to be uncorrelated with the student achievement

Table 2. Correlation coefficients between standardized exam results and different school characteristics

\begin{tabular}{lc}
\hline Share of students with special needs & -0.13 \\
$\begin{array}{l}\text { Additional teacher education hours for special needs } \\
\text { students per student with special needs }\end{array}$ & 0.02 \\
$\begin{array}{l}\text { Share of minority students } \\
\text { Additional teacher education hours for minority students per } \\
\text { minority student }\end{array}$ & -0.14 \\
Log of number of pupils & -0.02 \\
Combined schools & 0.03 \\
\hline
\end{tabular}

\footnotetext{
${ }^{13}$ There is a national rule saying that non-certified teachers, that is, teachers without formal teacher education, can only be appointed as a teacher if no certified teachers are willing to accept the job. Further, non-certified teachers can only be appointed on one-year contracts, see Bonesrønning et al. (2005) for details.
} 


\section{Individual characteristics}

As discussed in Section 2, teacher turnover is likely to depend on individual mobility costs, and the valuation of different school properties might differ between teachers. Hence it seems important to include relevant teacher characteristics in the model to reveal truthful estimates of the variable of interest. A general hypothesis is that as more settled a teacher is, the higher is the mobility cost. To capture this notion, we include several teacher characteristics.

The number of school aged children (6-18 years of age) are expected to increase mobility costs, while the number of children below six years of age may hasten mobility because the mobility costs increases when the children starts at school. Married teachers are likely to have higher mobility costs than divorced and never-married teachers, and mobility costs probably increase with age. In addition, proximity to place of childhood may be important for the quit behavior. The evidence in Boyd et al. (2005) strongly suggests that teachers prefer to work close to where they grew up. We have information on which school district teachers are born and where they lived at age ten. Since the local labor market regions typically cover several school districts, we construct a dummy variable for whether the teacher is born in the same local labor market as she is working. Since there are some missing observations for this variable, we also include a dummy variable for whether the birth region is unknown. ${ }^{14}$

Stinebrickner (1998) finds that women are more likely to leave teaching than men. To control for the possibility that female teachers might have a different quit behavior than male teachers we include a dummy variable for gender. In addition, we include a dummy variable for whether the teacher is on leave with pay, mostly maternity leaves, and a dummy variable for whether the teacher is working part time. Teachers have three to six years of higher education (colleges and universities). Dummy variables for educational level are included.

In standard utility theory, increased salary has a negative effect on turnover. However, up to the school year 2000-01, the Norwegian teacher wage was completely determined by national bargains between the teacher union and the central government, and was solely determined by the amount of formal education (included in the model) and experience (in a nonlinear way). Because there have been some limited local flexibility in the later years, we include the log of the teacher wage (corrected for working time) in the model, but with the caution that this variable may pick up other aspects of the quitting behavior as long as the

\footnotetext{
${ }^{14}$ When the birth region is unknown, it is replaced by the region where the teacher lived at age ten. For about 10 percent of the observations, both the school district of birth and at age 10 are missing.
} 
factors determining the wage level are not fully controlled for. Anyway, the prediction is a negative effect in accordance with the findings in for example Murnane and Olsen (1989), Dolton and van der Klaauw (1995, 1999), and Imazeki (2002).

\section{Regional characteristics}

Finally we utilize regional data to create variables at the school district level that may influence the teacher behavior. That is the unemployment rate, the share of immigrants, the share of divorced people, population size, and a measure of the settlement-pattern. In particular high unemployment rate are expected to have a negative effect on the probability to leave teaching, and population size are expected to have a positive effect on within school districts move because the choice set of schools for the teachers increases. In addition, a full set of dummy variables for labor market region is included. Among other things, this control for different choice sets for teachers in different regions. In essence, the analysis then allows for different behaviors of teachers currently working in schools with similar student achievement, but where the schools are located in regions where the student achievement in the neighboring schools differs.

Descriptive statistics for the variables used in the analysis are presented in Appendix Table A1 for the sample used in the baseline model. For the baseline model, covering the school years 1998-99 to 2000-01, there are 60,485 observations of 25,363 teachers in 1,062 schools. The average age of the teachers is 45 years, 70 percent is married, they have on average 0.66 school aged children, and only 37 percent is working in the same labor market region as born.

\section{Estimation results}

The estimation results for the school characteristics are reported in Table 3, while the effects of the other variables in the model are reported in Appendix Table 2. The effects of teacher characteristics are mainly as expected. For example, the quit propensity is generally negatively related to age, the number of school aged children and whether the teacher live in the birth region. For the latter two variables, there are strong effects on leaving the local labor market and none effects on within school districts moves. Divorced teachers have in general a higher quit propensity than single teachers who have never been married, while married teachers and female teachers have a lower propensity to quit for a school in another labor market as well as out of the education sector. Regarding moves out of the education sector, 
there is a positive effect of working part time, and negative effects of having higher education of medium length ( 4 or 5 years) and the salary. ${ }^{15}$ Regarding the variables at the school district level, all effects of unemployment and population size are negative except for within school district moves.

Student performance seems to have a negative effect on teacher turnover. The effect is negative and significant at least at 10 percent level for all types of moves identified. Evaluated at predicted quitting probabilities for mean values of the independent variables, an increase of one unit in student achievement (about 1.5 standard deviations) decreases the probability to move to another school in the same school district, to another school district in the same labor market region, across labor market regions, and to leave public schools by $0.31,0.17,0.28$ and 0.26 percentage points, respectively. In total, the marginal reduction in quitting propensity is 1.02 percentage points, which is a significant amount compared to the mean quitting propensity of about ten percent. The results are in line with Hanushek et al. (2004), but contradicts the findings by Scafidi et al. (2003) who conclude that students' test scores do not play an important role in the teachers' decision whether or not to leave the initial school.

The strong effect on mobility to schools in another labor market region indicates that teachers not only search for a good match for given residence, but residential change is also related to student performance. If one is dissatisfied with the current working conditions, and thereby wants to shift working place, the results indicate that both the willingness to change residence and the willingness to leave public schools increase. Notice that all effects are conditional on dummy variables for regional labor markets. The results must therefore be interpreted as the effect of relative achievement compared to other schools in the same labor market region.

\footnotetext{
${ }^{15}$ The salary is mainly decided by experience and education in a nonlinear and interacting way. The salary is included instead of including these variables in a very flexible form, also recognizing that there is some local discretion on the salary from 2000-01 and onwards. The negative and significant effect on moves out of public schools is pretty strong. This may indicate that the least experienced and least educated teachers are most likely to leave public schools, but may also be a direct effect of the wage level.
} 
Table 3. The baseline model. The comparison group is staying teachers.

\begin{tabular}{|c|c|c|c|c|}
\hline & $\begin{array}{l}\text { Moving to a school } \\
\text { in the same school } \\
\text { district. }\end{array}$ & $\begin{array}{l}\text { Moving to a school in } \\
\text { another school district } \\
\text { in the same labor } \\
\text { market region. }\end{array}$ & $\begin{array}{l}\text { Moving to a school } \\
\text { in another labor } \\
\text { market region. }\end{array}$ & $\begin{array}{l}\text { Moving out of } \\
\text { public schools }\end{array}$ \\
\hline $\begin{array}{l}\text { Student performance } \\
\text { Average student achievement (non } \\
\text { leaded value) }\end{array}$ & $\begin{array}{l}-0.09 \\
(1.77)^{*} \\
{[-0.31]}\end{array}$ & $\begin{array}{l}-0.19 \\
(2.20)^{* *} \\
{[-0.17]}\end{array}$ & $\begin{array}{c}-0.13 \\
(2.26)^{* *} \\
{[-0.28]}\end{array}$ & $\begin{array}{l}-0.06 \\
(1.94)^{*} \\
{[-0.26]}\end{array}$ \\
\hline \multicolumn{5}{|l|}{ Other school characteristics } \\
\hline Share of students with special needs & $\begin{array}{l}-0.23 \\
(0.16) \\
{[-0.52]}\end{array}$ & $\begin{array}{l}-1.08 \\
(0.57) \\
{[-0.61]}\end{array}$ & $\begin{array}{l}-0.27 \\
(0.18) \\
{[-0.28]}\end{array}$ & $\begin{array}{l}-0.79 \\
(0.99) \\
{[-3.67]}\end{array}$ \\
\hline $\begin{array}{l}\text { Additional teacher education hours } \\
\text { for special needs students per student } \\
\text { with special needs } / 100\end{array}$ & $\begin{array}{l}-0.01 \\
(0.13) \\
{[-0.03]}\end{array}$ & $\begin{array}{l}-0.07 \\
(1.05) \\
{[-0.04]}\end{array}$ & $\begin{array}{l}-0.07 \\
(1.47) \\
{[-0.10]}\end{array}$ & $\begin{array}{c}0.001 \\
(0.02) \\
{[0.002]}\end{array}$ \\
\hline Share of minority students & $\begin{array}{c}0.22 \\
(0.35) \\
{[0.88]}\end{array}$ & $\begin{array}{l}-1.36 \\
(0.88) \\
{[-0.77]}\end{array}$ & $\begin{array}{c}-0.83 \\
(1.37) \\
{[-0.98]}\end{array}$ & $\begin{array}{c}-1.21 \\
(3.42)^{* *} \\
{[-5.69]}\end{array}$ \\
\hline $\begin{array}{l}\text { Additional teacher education hours } \\
\text { for minority students per minority } \\
\text { student/100 }\end{array}$ & $\begin{array}{c}0.08 \\
(2.04)^{* *} \\
{[0.30]}\end{array}$ & $\begin{array}{l}-0.03 \\
(0.50) \\
{[-0.02]}\end{array}$ & $\begin{array}{c}0.02 \\
(0.43) \\
{[1.08]}\end{array}$ & $\begin{array}{c}0.02 \\
(0.82) \\
{[6.07]}\end{array}$ \\
\hline $\log$ of number of pupils & $\begin{array}{l}-1.32 \\
(2.04)^{* *} \\
{[-3.79]}\end{array}$ & $\begin{array}{l}-0.84 \\
(0.98) \\
{[-0.47]}\end{array}$ & $\begin{array}{l}-0.61 \\
(1.15) \\
{[-0.72]}\end{array}$ & $\begin{array}{l}-0.39 \\
(1.03) \\
{[-1.67]}\end{array}$ \\
\hline log of pupil squared & $\begin{array}{c}0.11 \\
(1.66)^{*} \\
{[0.31]}\end{array}$ & $\begin{array}{l}0.08 \\
(0.98) \\
{[0.04]}\end{array}$ & $\begin{array}{l}0.06 \\
(1.24) \\
{[0.10]}\end{array}$ & $\begin{array}{l}0.04 \\
(1.19) \\
{[0.17]}\end{array}$ \\
\hline $\begin{array}{l}\text { Logarithm to total number of teacher } \\
\text { education hours per student }\end{array}$ & $\begin{array}{l}0.38 \\
(0.82) \\
{[1.04]}\end{array}$ & $\begin{array}{l}-0.50 \\
(0.64) \\
{[-0.32]}\end{array}$ & $\begin{array}{l}0.49 \\
(1.22) \\
{[0.60]}\end{array}$ & $\begin{array}{l}0.40 \\
(1.35) \\
{[1.83]}\end{array}$ \\
\hline $\begin{array}{l}\text { The share of uncertified teachers } \\
\text { employed at school }\end{array}$ & $\begin{array}{c}-0.04 \\
(0.08) \\
{[-0.31]}\end{array}$ & $\begin{array}{c}0.61 \\
(0.77) \\
{[0.33]}\end{array}$ & $\begin{array}{c}1.20 \\
(2.55)^{* *} \\
{[1.48]}\end{array}$ & $\begin{array}{c}0.88 \\
(3.10)^{* *} \\
{[4.09]}\end{array}$ \\
\hline Combined schools & $\begin{array}{c}0.08 \\
(0.79) \\
{[0.23]}\end{array}$ & $\begin{array}{c}0.04 \\
(0.30) \\
{[0.03]}\end{array}$ & $\begin{array}{c}-0.02 \\
(-0.16) \\
{[-0.03]}\end{array}$ & $\begin{array}{c}0.01 \\
(0.11) \\
{[0.04]}\end{array}$ \\
\hline Predicted probability & 0.03 & 0.006 & 0.013 & 0.05 \\
\hline
\end{tabular}

Note. 60485 observations. The model is estimated by the multinomial logit method. Asymptotic t-values in parentheses, calculated based on standard errors corrected to account for within-school clustering of errors, and marginal effects in percentage points in brackets. ${ }^{*}$ and ${ }^{* *}$ denotes significance at ten and five percent level respectively. In addition to the reported variables, the variables reported in Appendix Table A2, labor market region specific effects and year specific effects are included in the model. 
The effects of the other school characteristics are merely insignificant. The student composition, the share of students with special needs and the share of minority students and the amount of extra resources directed to this students, turn out to have small effects. This contradicts the findings in, for example, Falch and Strøm (2005), Scafidi et al. (2003) and Hanushek et al. (2004), who all find that teachers tend to leave schools with a high share of minority or black students. ${ }^{16}$ Regarding school size, the log of the number of pupils has a Ushaped effect on teacher turnover, although only significant for within district moves. Resource use has also in general small effects, see Falch and Strøm (2005) for a discussion of this result. Regarding the share of uncertified teachers at school, there are positive effects on moves to a school in another labor market region and out of public schools, which must be interpreted as the effect of the relative share of uncertified teacher employed compared to other schools in the same labor market region.

In the next sections we change the baseline model specification in different ways to investigate the robustness of the effect of student achievement.

\subsection{Alternative measures on student achievement}

In this section we replace the measure of student achievement used in the baseline model above with several different alternative measures, including lagged and leaded values of the examination grades, grades given by teachers, and the share of low performing students

The present value of student achievement is related to the students finishing their lower secondary education. But if teachers are forward looking, they should be interested in the ability of the students at school the next school year(s). Empirically this does not need to be important if the test scores are reasonable constant over time. Table 4 shows that the within-school correlations between the exam results for the students at 10th grade in various years are in the range $0.30-0.35$. This implies that there are important changes in student achievement at a particular school over time. Using leaded achievement of the 10th graders in the model may then be attractive because this characterizes the students that will be at the school the next school year. On the other hand, leaded achievement may depend on whether specific teachers choose to stay or leave the school today. If it is expected that poor students

\footnotetext{
${ }^{16}$ The divergent results compared to earlier Norwegian studies (Falch and Strøm, 2005) seem mainly to be driven by different samples used. Our sample covers the years 1999-2000 to 2001-02, while Falch and Strøm investigated teacher moving pattern over a 7-years-period from 1992-93 to 1998-99, including both primary and lower secondary schools. The effects of the share of minority students and students with special needs in our model are independent of whether student achievement is included in the model or not, or whether the different measures of teacher education hours are included in the model or not. However, excluding all family characteristics (which is not included in Falch and Strøm) increases the effects in expected direction somewhat.
} 
will be at the school the next year, and the most qualified teachers react strongest to this expectations because they have more alternatives than other teachers, the estimated effect by using leaded achievement will be biased away from zero compared to the true effect. This mechanism is less relevant by using present and lagged values. Instead, present achievement, and to a greater extent lagged achievement, may be an imprecise indicator of the ability of the students the next year, which should bias the estimate of these measures against zero as with classical measurement error.

Table 4. Correlation across school years in average standardized exam results, weighted by the number of observations

\begin{tabular}{llll}
\hline & $\mathbf{1 9 9 9 - 2 0 0 0}$ & $\mathbf{2 0 0 0 - 0 1}$ & $\mathbf{2 0 0 1 - 0 2}$ \\
\hline $\mathbf{1 9 9 9 - 2 0 0 0}$ & 1 & & \\
$\mathbf{2 0 0 0 - 0 1}$ & 0.35 & 1 & 1 \\
$\mathbf{2 0 0 1 - 0 2}$ & 0.30 & 0.30 & 1 \\
\hline
\end{tabular}

The results for separate regressions are reported in Table 5. Overall there are negative effects on all types of moves for both leaded, present and lagged measures of student achievement. In all cases there is a significant effect on within school district moves. Regarding the other types of moves, the effect varies to some extent across the specifications. There is no effect of lagged achievement, while the effect of leaded achievement is only significant for moves to another labor market region. The differences in the estimated coefficients must be related to the fact that the correlation over time in achievement is not overwhelming. In addition, there are also different samples used in the different specifications. When lagged achievement is used, the school year 2001-02 is excluded from the analysis (reducing the sample by $1 / 3$ ), while when leaded achievement is used, the sample consists of the school years 1998-99 through 2000-01.

Turning to the share of low-performing students, there are positive effects of this variable on the propensity for all types of quits of about the same order as for average achievement For example, when the share of low-performing students decreases by 0.16 (about 1.5 standard deviations), the probability to move to another school in the same school districts and out of public schools increase with about 0.22 and 0.27 percentage points, respectively. The effect on within school district moves is only marginally significant at 10 
present level, while the effects on quits out of public schools are significant at 5 percent level. $^{17}$

Table 5. The effects of alternative measures on student performance. The comparison group is staying teachers

\begin{tabular}{cccc}
\hline Moving to a school & $\begin{array}{c}\text { Moving to a school in } \\
\text { in the same school } \\
\text { another school district } \\
\text { in the same labor } \\
\text { in another labor } \\
\text { market region. }\end{array}$ & $\begin{array}{c}\text { Moving out of } \\
\text { mablic set region. }\end{array}$ \\
\hline
\end{tabular}

\section{Examination grades}

Average student achievement (leaded value)

Average student achievement (present value)

Average student achievement (lagged value)

Share of low-performing students (present value)

$\begin{array}{cccc}-0.16 & -0.08 & -0.19 & -0.04 \\ (3.07)^{* *} & (0.87) & (3.28)^{* *} & (1.33) \\ {[-0.40]} & {[-0.04]} & {[-0.25]} & {[-0.13]} \\ -0.09 & -0.19 & -0.13 & -0.06 \\ (1.77)^{*} & (2.20)^{* *} & (2.26)^{* *} & (1.94)^{*} \\ {[-0.31]} & {[-0.17]} & {[-0.28]} & {[-0.26]} \\ -0.28 & -0.02 & 0.03 & 0.02 \\ (2.96)^{* *} & (0.14) & (0.36) & (0.41) \\ & & & \\ 0.50 & 0.62 & 0.36 & 0.38 \\ (1.66)^{*} & (1.34) & (1.25) & (2.19)^{* *} \\ {[1.40]} & {[0.35]} & {[0.41]} & {[1.69]}\end{array}$

\section{Grades given by teachers}

Average student achievement (leaded value)

Average student achievement (present value)

Average student achievement (lagged value)

Share of low-performing students (present value)

$\begin{array}{cccc}-0.38 & 0.18 & -0.29 & -0.10 \\ (2.51)^{* *} & (0.78) & (1.85)^{*} & (1.25) \\ {[-1.10]} & {[0.12]} & {[-0.38]} & {[-0.40]} \\ -0.27 & -0.23 & -0.36 & -0.26 \\ (2.03)^{* *} & (1.10) & (2.55)^{* *} & (2.01)^{* *} \\ {[-0.74]} & {[-0.13]} & {[-0.44]} & {[-0.69]} \\ -0.31 & 0.36 & -0.28 & -0.07 \\ (1.45) & (1.07) & (1.22) & (0.52) \\ & & & \\ 1.17 & 0.05 & 0.90 & 0.62 \\ (2.70)^{* *} & (0.08) & (1.84)^{*} & (2.37)^{* *} \\ {[3.28]} & {[0.02]} & {[1.07]} & {[2.71]}\end{array}$

Note. The models are estimated by the multinomial logit method. Asymptotic t-values in parentheses, calculated based on standard errors corrected to account for within-school clustering of errors, and marginal effects in percentage pints in brackets. $*$ and $* *$ denotes significance at ten and five percent level respectively. The specifications of all models are as in baseline model presented in Table 4 except as indicated.

\footnotetext{
${ }^{17}$ In a "horse race" competition between average achievement and the share of low performing students (using present values), average achievement turns out as a "winner". In a simple logit model where both average achievement and the share of low performing students are included, the effect of average achievement is significant at ten percent level (the marginal effect is -0.72), while the effect of the share of low performing students becomes clearly insignificant.
} 
The results for grades given by teachers are very similar to the results above. ${ }^{18}$ Out of 12 coefficients estimated for average achievement, five are significant at ten percent level compared to seven significant effects for examination grades. One of the differences is that there are no significant effects of lagged grades given by teachers. ${ }^{19}$ On the other hand, the effect of the share of low performing students is slightly stronger when teacher grades are used instead of examination grades. ${ }^{20}$

Overall, the results are almost qualitatively independent of whether leaded or nonleaded measures of student performance are used in the model. This indicates that neither a bias related to the simultaneity bias of the type indicated above or a measurement error of using grades that are not directly related to the student population the next year are large. On the other hand, the effects of lagged measures are smaller, which may indicate that this is a weaker measure of the student achievement relevant for teacher behavior.

\subsection{Sub-samples based on teacher characteristics}

Referring to equation (4), different types of teachers may value non-pecuniary rewards differently. In the following we allow for different responses to all explanatory variables across teacher types by dividing the full sample into different sub-samples based upon various characteristics of the particular teacher. The model specification is equal to the baseline model. Table 6 presents the results for student achievement.

\footnotetext{
${ }^{18}$ The correlation over time for teacher grades is in the range 0.39-0.44.

${ }^{19}$ In a "horse-race" competition between average examination grades and average grades given by teachers using present values in a simple logit model, the effect of examination grades are significant at five percent level (the marginal effect is -0.63) while the effect of grades given by teachers is clearly insignificant.

${ }^{20}$ The effect of the other variables in the model are mainly unaffected by the changes in the model specifications presented in Table 4. However, when using leaded and lagged values there are some small changes compared to the baseline model, probably because of different samples used (the school years 1998-99 to 2000-01 and 200001 to 2001-02, respectively, instead of the school years 1999-00 to 2001-02). This is in particular true for the effects of the different measures of student composition, indicating that these effects are not stable over time.
} 
Table 6. The effect of average student performance for different sub-samples. The comparison group is staying teachers

\begin{tabular}{|c|c|c|c|c|c|}
\hline Sub-sample & $\begin{array}{l}\text { Moving to a school } \\
\text { in the same school } \\
\text { district. }\end{array}$ & $\begin{array}{l}\text { Moving to a school in } \\
\text { another school district } \\
\text { in the same labor } \\
\text { market region. }\end{array}$ & $\begin{array}{l}\text { Moving to a school } \\
\text { in another labor } \\
\text { market region. }\end{array}$ & $\begin{array}{l}\text { Moving out of } \\
\text { public schools }\end{array}$ & $\begin{array}{c}\text { Number of } \\
\text { observations }\end{array}$ \\
\hline Above 40 years & $\begin{array}{l}-0.07 \\
(1.03) \\
{[-0.20]}\end{array}$ & $\begin{array}{c}-0.22 \\
(1.68)^{*} \\
{[-0.09]}\end{array}$ & $\begin{array}{c}0.04 \\
(0.44) \\
{[0.03]}\end{array}$ & $\begin{array}{l}-0.06 \\
(1.40) \\
{[-0.22]}\end{array}$ & 44208 \\
\hline Below 40 years & $\begin{array}{c}-0.15 \\
(2.01)^{* *} \\
{[-0.39]}\end{array}$ & $\begin{array}{l}-0.18 \\
(1.47) \\
{[-0.14]}\end{array}$ & $\begin{array}{c}-0.24 \\
(3.43)^{* *} \\
{[-0.66]}\end{array}$ & $\begin{array}{c}-0.07 \\
(1.45) \\
{[-0.41]}\end{array}$ & 16277 \\
\hline Married & $\begin{array}{l}-0.06 \\
(0.96) \\
{[-0.15]}\end{array}$ & $\begin{array}{l}-0.15 \\
(1.34) \\
{[-0.70]}\end{array}$ & $\begin{array}{l}-0.11 \\
(1.26) \\
{[-0.08]}\end{array}$ & $\begin{array}{c}-0.11 \\
(2.75) * * \\
{[-0.51]}\end{array}$ & 41784 \\
\hline Non-married & $\begin{array}{c}-0.18 \\
(2.53)^{* *} \\
{[-0.51]}\end{array}$ & $\begin{array}{c}-0.25 \\
(1.82)^{*} \\
{[-0.15]}\end{array}$ & $\begin{array}{c}-0.15 \\
(1.84)^{*} \\
{[-0.28]}\end{array}$ & $\begin{array}{c}0.02 \\
(0.33) \\
{[0.17]}\end{array}$ & 18701 \\
\hline School aged children & $\begin{array}{c}-0.18 \\
(2.74)^{* *} \\
{[-0.51]}\end{array}$ & $\begin{array}{l}-0.17 \\
(1.29) \\
{[-0.10]}\end{array}$ & $\begin{array}{c}0.16 \\
(1.76)^{*} \\
{[0.15]}\end{array}$ & $\begin{array}{c}-0.08 \\
(1.41) \\
{[-0.36]}\end{array}$ & 24108 \\
\hline Non school aged children & $\begin{array}{l}-0.02 \\
(0.31) \\
{[-0.04]}\end{array}$ & $\begin{array}{c}-0.21 \\
(1.78)^{*} \\
{[-0.10]}\end{array}$ & $\begin{array}{c}-0.24 \\
(3.25)^{* *} \\
{[-0.37]}\end{array}$ & $\begin{array}{l}-0.06 \\
(1.38) \\
{[-0.26]}\end{array}$ & 36377 \\
\hline $\begin{array}{l}\text { Working in the same labor } \\
\text { market region as born }\end{array}$ & $\begin{array}{c}-0.20 \\
(2.41)^{* *} \\
{[-0.60]}\end{array}$ & $\begin{array}{c}-0.24 \\
(1.80)^{*} \\
{[-0.16]}\end{array}$ & $\begin{array}{l}-0.15 \\
(1.05) \\
-[0.07]\end{array}$ & $\begin{array}{l}-0.03 \\
(0.64) \\
{[-0.10]}\end{array}$ & 22084 \\
\hline $\begin{array}{l}\text { Not working in the same } \\
\text { labor market region as born }\end{array}$ & $\begin{array}{l}-0.04 \\
(0.74) \\
{[-0.10]}\end{array}$ & $\begin{array}{l}-0.18 \\
(1.55) \\
{[-0.10]}\end{array}$ & $\begin{array}{c}-0.12 \\
(1.92)^{*} \\
{[-0.19]}\end{array}$ & $\begin{array}{c}-0.08 \\
(1.93)^{*} \\
{[-0.36]}\end{array}$ & 38401 \\
\hline Working part time & $\begin{array}{c}-0.13 \\
(1.44) \\
{[-0.35]}\end{array}$ & $\begin{array}{c}-0.17 \\
(0.91) \\
{[-0.08]}\end{array}$ & $\begin{array}{c}-0.26 \\
(2.08)^{* *} \\
{[-0.22]}\end{array}$ & $\begin{array}{c}-0.09 \\
(1.73)^{*} \\
{[-0.61]}\end{array}$ & 13847 \\
\hline Working full time & $\begin{array}{l}-0.08 \\
(1.38) \\
{[-0.19]}\end{array}$ & $\begin{array}{c}-0.19 \\
(1.92)^{*} \\
{[-0.10]}\end{array}$ & $\begin{array}{c}-0.11 \\
(1.69)^{*} \\
{[-0.13]}\end{array}$ & $\begin{array}{c}-0.04 \\
-(1.05) \\
{[-0.10]}\end{array}$ & 46638 \\
\hline Female & $\begin{array}{c}-0.05 \\
(0.67) \\
{[-0.13]}\end{array}$ & $\begin{array}{c}-0.31 \\
(2.61)^{* *} \\
{[-0.18]}\end{array}$ & $\begin{array}{l}-0.09 \\
(1.30) \\
{[-0.11]}\end{array}$ & $\begin{array}{l}-0.05 \\
(1.22) \\
{[-0.22]}\end{array}$ & 35294 \\
\hline Male & $\begin{array}{c}-0.16 \\
(2.34)^{* *} \\
{[-0.45]}\end{array}$ & $\begin{array}{l}-0.02 \\
(0.17) \\
{[-0.01]}\end{array}$ & $\begin{array}{c}-0.20 \\
(2.24)^{* *} \\
{[-0.23]}\end{array}$ & $\begin{array}{l}-0.08 \\
(1.60) \\
{[-0.34]}\end{array}$ & 25191 \\
\hline
\end{tabular}

Note. The model is estimated by the multinomial logit method. Asymptotic t-values in parentheses, calculated based on standard errors corrected to account for within-school clustering of errors, and marginal effects in percentage points in brackets. ${ }^{*}$ and $* *$ denotes significance at ten and five percent level respectively. The specifications of all models are as in baseline model presented in table 4. 
Out of the 48 estimated coefficients in Table 6, all but three are negative. Student achievement seems to have a negative effect on the quit propensity for all types of teachers, but there are important quantitative differences across teacher types. These differences should be interpreted as a result of different mobility costs. For example, there are stronger effects on young teachers (below 40 years of age) than old teachers for all types of quits. The same is true for non-married teachers versus married teachers, except that student achievement has a stronger effect on the propensity to leave the school sector for married teachers. Regarding subsamples based on other teacher characteristics, there are more heterogeneous effects across destinations. For example, teachers with school aged children and teachers working in the same labor market region as born react stronger on student achievement on moves between schools within the labor market region than others, while teachers without school aged children and not working in the same labor market region as born react strongest for moves out of schools in the labor market region. These results seem reasonable in light of differences in mobility costs. Both young teachers, non-married teachers, teachers without school aged children and teachers born in a different labor market region are likely to have relatively small mobility costs for moves out of the local labor market. Part time working and full time working teachers seem to react almost similar to student achievement, while male teachers are more responsive when it comes to leaving schools in the local labor market.

\subsection{Model specification}

The multinomial logit model relies on some strong underlying assumptions, for example the assumption of independence of irrelevant alternatives. It may therefore be useful to estimate a simpler logit model. In order to make an attempt to distinguish between different types of moves, Table 7 presents the result for two different specification of the dependent variable. The first model investigates determinants of quitting the present school, which is the sum of all quits considered above. The results are close to the average effects across destinations in Table 3. For example, an increase in average student achievement by 1.5 standard deviation decreases the quit propensity with 0.8 percentage points. The second model investigates determinants of quitting public schools, focusing on one of the quit types discussed above. In this model there are few significant effects, and the effect of student achievement is only marginally significant at 10 percent level. 
Table 7. Logit models for school quits and quits out of education

\begin{tabular}{|c|c|c|}
\hline Dependent variable & $\begin{array}{l}\text { The teacher is not at the same } \\
\text { school the next school year }\end{array}$ & $\begin{array}{c}\text { The teacher is not in public schools } \\
\text { the next school year }\end{array}$ \\
\hline \multicolumn{3}{|l|}{ Student performance } \\
\hline \multirow[t]{3}{*}{ Average student achievement } & -0.09 & -0.06 \\
\hline & $(3.34)^{* *}$ & $(1.68)^{*}$ \\
\hline & {$[-0.81]$} & {$[-0.29]$} \\
\hline \multicolumn{3}{|l|}{ Other school characteristics } \\
\hline \multirow[t]{3}{*}{ Share of students with special needs } & -0.56 & -0.75 \\
\hline & $(0.80)$ & $-(0.95)$ \\
\hline & {$[-5.04]$} & {$[-3.56]$} \\
\hline \multirow{3}{*}{$\begin{array}{l}\text { Additional teacher education hours } \\
\text { for special needs students per student } \\
\text { with special needs } / 100\end{array}$} & -0.01 & 0.003 \\
\hline & $(0.62)$ & $(0.15)$ \\
\hline & {$[-0.10]$} & {$[0.01]$} \\
\hline \multirow[t]{3}{*}{ Share of minority students } & -0.70 & -1.19 \\
\hline & $(2.26)$ & $-(3.39)^{* *}$ \\
\hline & {$[-6.3]$} & {$[-5.65]$} \\
\hline \multirow{3}{*}{$\begin{array}{l}\text { Additional teacher education hours } \\
\text { for minority students per minority } \\
\text { student } / 100\end{array}$} & 0.04 & 0.01 \\
\hline & $(1.82)^{*}$ & $(0.67)$ \\
\hline & {$[-0.36]$} & {$[-0.05]$} \\
\hline \multirow[t]{3}{*}{$\log$ of number of pupils } & -0.81 & -0.26 \\
\hline & $(2.38)^{* *}$ & $(0.69)$ \\
\hline & {$[-7.29]$} & {$[-1.24]$} \\
\hline \multirow[t]{3}{*}{ log of pupil squared } & 0.08 & 0.03 \\
\hline & $(2.27)^{* *}$ & $(0.86)$ \\
\hline & [0.72] & {$[0.14]$} \\
\hline \multirow{3}{*}{$\begin{array}{l}\text { Logarithm to total number of teacher } \\
\text { education hours per student }\end{array}$} & 0.34 & 0.34 \\
\hline & $(1.40)$ & $(1.28)$ \\
\hline & {$[3.06]$} & {$[1.62]$} \\
\hline \multirow{3}{*}{$\begin{array}{l}\text { The share of uncertified teachers } \\
\text { employed at school }\end{array}$} & 0.74 & 0.83 \\
\hline & $(3.03)^{* *}$ & $(2.95)^{* *}$ \\
\hline & {$[6.66]$} & {$[3.94]$} \\
\hline \multirow[t]{3}{*}{ Combined schools } & 0.04 & 0.002 \\
\hline & $(0.88)$ & $(0.04)$ \\
\hline & {$[0.36]$} & {$[0.01]$} \\
\hline Predicted probability & 0.10 & 0.05 \\
\hline Number of observations & 60485 & 60485 \\
\hline
\end{tabular}

Note. 60485 observations. The model is estimated by the multinomial logit method. Asymptotic t-values in parentheses, calculated based on standard errors corrected to account for within-school clustering of errors, and marginal effects in percentage points in brackets. ${ }^{*}$ and $* *$ denotes significance at ten and five percent level respectively. In addition to the reported variables, the same teacher and regional variables reported in Appendix Table A2, labor market region specific effects and year specific effects are included in the model. 
So far teachers on leave without pay are regarded as quitters. About 18 percent of the observed quits are teachers returning to the same school after one year, mainly related to within school district moves and moves out of teaching. ${ }^{21}$ However, redefining these kinds of moves as staying teachers has very small effects on the results. ${ }^{22}$

Even though the present analysis includes a large number of school characteristics, no direct measure of parental background of the students is included. Information of parental background is, however, available for the last year in our sample. Imposing these measures on all three years of the sample does not change the results much. By for example including these variables in the first logit model of Table 7, the effect of student achievement is slightly reduced to -0.66 .

The present analysis also includes a large number of teacher characteristics, but still unobserved teacher characteristics, as for example the teachers' mission to teach low performing students, may bias the estimated effects. One way of taking this into account is to include fixed teacher effects. Including fixed teacher effects may be problematic, however, within a three year long panel because only teachers that move at least once during the empirical period can be included in the model. Teachers that do not move will not contribute to the log-likelihood. For this reason the sample is reduced by about 86 percent. The results of such models are sensitive to which achievement measure that is included. For the measure used in our baseline model, there is basically no effect of achievement. Using leaded achievement, however, the effect is negatively significant at 5 percent level.

\section{Conclusions}

This paper indicates that teachers tend to quit schools with low student performance. This result must be interpreted within a wage setting regime which yields little variation in the wages across schools. When teachers are not compensated for working conditions, students most in need of good schools and high-quality teachers may be harmed. The effect of high teacher turnover on teacher quality, however, depends on the possibility of the schools to attract new and competent teachers. We have argued that systematic effects on the quit rate are likely to reflect the attractiveness of the schools. In this case, our results indicate that reduced student performance makes the school less attractive from the "average" teachers'

\footnotetext{
${ }^{21}$ For teachers leaving a school for another school in the same school district, another school district in the same labor market region, another labor market region, or out of teaching, 12.2, 5.5, 4.7, and 19.2 percent, respectively, return to the same school after one year.

${ }_{22}^{22}$ The marginal effects of student achievement in the baseline model changes to $-0.19,-0.11,-0.16$ and -0.21 for the four different types of moves, respectively.
} 
point of view, reducing the pool of teachers that want to teach at the school. Not only must the school hire more of the teachers in the applicant pool, the number of potential matches will also be reduced. ${ }^{23}$

This effect is likely to be critical mainly in situations with low teacher supply. When the overall supply of well-qualified teachers is relatively low compared to the demand for teachers, teachers leaving a school can be hard to replace, in particular when teacher mobility is related to factors making the school unattractive. Betts et al. (2000) and Jepsen and Rivkin (2002) show that the mandated class size reduction in California in 1996 increased the share of less-experienced teachers and teachers who lack a full credential. Most importantly, the evidence indicates a substantial teacher movement away from high-poverty schools to lowpoverty schools and from schools serving mainly nonwhite students to schools serving white students. Jepsen and Rivkin (2002) argue that this movement in some cases fully offset the benefits from smaller classes.

The importance of a negative influence of student achievement on teacher turnover is therefore expected to be more severe in for example the UK experiencing teacher shortages (Dolton et al., 2002) than in for example Switzerland with a high teacher supply (Wolter and Denzler, 2003). In Norway, the importance of this effect may have been reduced in the $21 \mathrm{st}$ century as the teacher wage increased and teacher supply improved. An OECD working paper argues that there "is a widespread belief that several countries in the OECD area suffer from shortages of teachers in particular subject areas, grade levels, or regions of the country" (Santiago, 2002 p. 11). To avoid unwanted distributional consequences of low teacher supply, one could think of wage setting institutions that compensate teachers serving low-performing students. This is an intricate situation, however, because then teacher incentives with respect to student performance may become completely wrong. The most reasonable policy change given the evidence that rigid wages tends to sort teachers in a harmful way for disadvantage students is to let teacher wages respond to at least some extent to local supply of and demand for teachers.

\footnotetext{
${ }^{23}$ This indicates that there is a negative correlation between teacher turnover and student achievement. In our data, the correlation between the share of teachers in permanent position that leave the school and average student achievement is -0.06
} 


\section{References}

Betts, J. R., K. S. Rueben and A. Danenberg (2000). Equal resources, equal outcomes? The distribution of school resources and student achievement in California. Public Policy Institute of California.

Bonesrønning, H., Falch, T. \& Strøm, B. (2005). Teacher sorting, teacher quality, and student composition. European Economic Review 49 (2), 457-483.

Besley, T., \& Ghatak, M. (2005). Competition and incentives with motivated agents. American Economic Review, (forthcoming).

Besley, T., \& Ghatak, M. (2003). Incentives, choice and accountability in the provision of public services. Oxford Review of Economic Policy 5, 21-33.

Boyd, D., Lankford, H., Loeb, S. \& Wyckoff, J. (2003): Analyzing the determinants of the matching of public school teachers to jobs: Estimating compensating differentials in imperfect labor markets. NBER Working Paper 9878.

Boyd, D., Lankford, H., Loeb, S. \& Wyckoff, J. (2005): The draw of home: How teachers' preferences for proximity disadvantage urban schools. Journal of Policy Analysis and Management 24 (1), 113-132.

Burdett, K. (1978). A theory of employee job search and quit rates. American Economic Review 68, 212-220.

Chevalier, A., P. Dolton and S. McIntosh (2002). Recruiting and retaining teachers in the UK: An analysis of graduate occupation choice from the 1960s to the 1990s. Discussion Paper No. 21, Centre for the Economics of Education.

Currie, J. (1991). Employment determination in a unionized public-sector labor market: The case of Ontario's school teachers. Journal of Labor Economics 9, 45-66.

Dolton, P., \& van der Klaauw, W. (1995). Leaving teaching in the UK: A duration analysis. Economic Journal 105, 431-444.

Dolton, P., \& van der Klaauw, W. (1999). The turnover of teachers: A competing risks explanation. Review of Economics and Statistics 81 (3), 543-552.

Falch, T. (2002). The supply of public sector services when they include quantity and quality dimensions. FinanzArchiv 58, 396-429.

Falch, T. (2003). Estimating the elasticity of labor supply to an enterprise utilizing a quasi-natural experiment. Working Paper no. 7/2003, Department of Economics, Norwegian University of Science and Technology. 
Falch, T., and B. Strøm (2005). Teacher turnover and non-pecuniary factors. Education of Economics Review (forthcoming).

Greenberg, D., \& McCall, J. (1974). Teacher mobility and allocation. Journal of Human Resources 9 (4), 480-502.

Greene, W.H. (1997). Econometric Analysis, third edition. Prentice Hall, New Jersey.

Gritz, M.R., \& Theobald, N.D. (1996). The effects of school district spending priorities on length of stay in teaching. Journal of Human Resources 31 (3), 477-512.

Hanushek, E.A. (2002). Publicly provided education. In Alan J. Auerbach and Martin

Feldstein (ed.), Handbook of Public Economics, (Amsterdam: North-Holland, 2002, pp.2047-2143).

Hanushek, E.A., Kain, J.F., \& Rivkin, S.G. (2004). Why public schools lose teachers. Journal of Human Resources 39 (2), 326-354.

Imazeki, J. (2002). Teacher Attrition and mobility in urban districts: Evidence from Wisconsin. In J.K. Rice and C. Roelke (eds.), Fiscal issues in urban schools; research in education: Fiscal policy and practice. Information Age Publishing Inc., Greenwich.

Jepsen, C., and S. Rivkin (2002). What is the tradeoff between smaller classes and teacher quality? NBER Working Paper 9205.

Lankford, H, Loeb, S. \& Wyckoff, J. (2002): Teacher sorting and the plight of urban schools: A descriptive analysis. Educational Evaluation and Policy Analysis 24 (1), 37-62.

Mont, D., \& Rees, D.I. (1996). The influence of classroom characteristics on high school teacher turnover. Economic Inquiry 34, 152-67.

Murnane, R.J., \& Olsen, R.J. (1989). The effect of salaries and opportunity costs on duration in teaching: Evidence from Michigan. Review of Economics and Statistics 71 (2), 347-352.

Rockoff, J.E. (2004). The Impact of Individual Teachers on Student Achievement: Evidence from Panel Data. American Economic Review 94 (2), 247-252.

Santiago, P. (2002). Teacher demand and supply: Improving teaching quality and addressing teacher shortages. OECD Education Working Paper No. 1.

Scafidi, B., D.L. Sjoquist and T.R. Stinebrickner (2003). The Relationship between school characteristics and teacher mobility. Mimeo.

Staiger, D., J. Spetz and C. Phibbs (1999). Is There Monopsony In the Labor Market? Evidence from a Natural Experiment, NBER Working Paper 7258.

Stinebrickner, T. (1998). An empirical investigation of teacher attrition. Economics of Education Review 17, 127-136. 
Stinebrickner, T. (2001). A dynamic model of teacher labor supply. Journal of Labor Economics 19 (1), 196-230.

Sullivan, D. (1989). Monopsony Power in the Market for Nurses. Journal of Law \& Economics, 32, S135-S178.

Wolter, S.C., and S. Denzler (2003). wage elasticity of the teacher supply in Switzerland. IZA Discussion paper No. 733. 
$\begin{array}{llll}\text { Mean } & \text { St. dev. } & \text { Minimum } & \text { Maximum }\end{array}$

Student performance

Examination grades

Average student achievement

$\begin{array}{cccc}-0.05 & 0.68 & -4.77 & 5.18 \\ 0.22 & 0.12 & 0 & 1 \\ & & & \\ 3.64 & 0.27 & 1.75 & 5.5 \\ 0.16 & 0.08 & 0 & 1 \\ & & & \\ 0.07 & 0.03 & 0 & 0.31 \\ 197.12 & 114.58 & 0 & 1900 \\ & & & \\ 0.06 & 0.10 & 0 & 0.87 \\ 85.69 & 105.26 & 0 & 1900 \\ & & & \\ 4.50 & 0.61 & 1.9 & 6.68 \\ 271 & 129.77 & 3 & 798 \\ & & & \\ 30.12 & 6.18 & 1.21 & 44.65 \\ 0.05 & 0.07 & 0 & 1 \\ 0.50 & 0.50 & 0 & 1\end{array}$

Average student achievement

\section{Grades given by teachers}

Share of low performing students

\section{Other school characteristics}

Share of students with special needs

Additional teacher education hours for special needs

students per student with special needs

Share of minority students

Additional teacher education hours for minority students

per minority student

Log of number of teacher education hours per student

Number of pupils

Log of number of pupils

Log of pupils squared

The share of uncertified teachers employed at school

Combined schools

0.50

0.50

0.70

0.46

Married

0.11

0.31

Divorced

0.20

Single

0.37

0.40

Working in the same labor market region as born

0.12

0.48

Birth region unknown

0.25

Part-time working

On leave

0.027

0.32

0.60

0.43

Female

0.66

0.16

Number of school children (children between 6 and 18

0.49

years)

Number of children beyond 6 years

Age

$0.24 \quad 0.57$

45.20

23663

$$
9.83
$$

2583.28

$\begin{array}{llll}0.03 & 0.19 & 0 & 1 \\ 0.75 & 0.44 & 0 & 1 \\ 0.17 & 0.37 & 0 & 1 \\ 0.05 & 0.22 & 0 & 1\end{array}$

\section{Regional characteristics}

Unemployment-rate in the local government

Population in local government

The share of people living in rural areas

$\begin{array}{cccc}0.04 & 0.02 & 0.01 & 0.25 \\ 61382.3 & 126935.60 & 246 & 508726 \\ 0.30 & 0.26 & 0 & 1 \\ 0.10 & 0.02 & 0.033 & 0.147 \\ 0.05 & 0.04 & 0.002 & 0.193\end{array}$




\section{Appendix Table 2. The effects of individual and regional characteristics on teacher} turnover. The comparison group is staying teachers.

\begin{tabular}{|c|c|c|c|c|}
\hline & $\begin{array}{l}\text { Moving to a school } \\
\text { in the same school } \\
\text { district. }\end{array}$ & $\begin{array}{l}\text { Moving to a school in } \\
\text { another school district } \\
\text { in the same labor } \\
\text { market region. }\end{array}$ & $\begin{array}{l}\text { Moving to a school } \\
\text { in another labor } \\
\text { market region. }\end{array}$ & $\begin{array}{l}\text { Moving out of } \\
\text { public schools }\end{array}$ \\
\hline \multicolumn{5}{|l|}{ Individual teacher characteristics } \\
\hline Married & $\begin{array}{c}0.03(0.36) \\
{[0.10]}\end{array}$ & $\begin{array}{l}0.25(1.46) \\
{[0.20]}\end{array}$ & $\begin{array}{c}-0.19(1.73)^{*} \\
{[-0.24]}\end{array}$ & $\begin{array}{c}-0.12(2.17) * * \\
{[-0.57]}\end{array}$ \\
\hline Divorced & $\begin{array}{c}0.27(2.62)^{* *} \\
{[0.73]}\end{array}$ & $\begin{array}{c}0.42(1.69)^{*} \\
{[0.24]}\end{array}$ & $\begin{array}{c}0.52(3.54)^{* *} \\
{[0.64]}\end{array}$ & $\begin{array}{c}0.18(2.45)^{* *} \\
{[0.77]}\end{array}$ \\
\hline $\begin{array}{l}\text { Working in the same labor market } \\
\text { region as born }\end{array}$ & $\begin{array}{c}0.03(0.51) \\
{[0.11]}\end{array}$ & $\begin{array}{c}0.38(2.81)^{* *} \\
{[0.23]}\end{array}$ & $\begin{array}{c}-1.15(10.89)^{* *} \\
{[-1.49]}\end{array}$ & $\begin{array}{c}-0.16(3.73)^{* *} \\
{[-0.77]}\end{array}$ \\
\hline Birth region unknown & $\begin{array}{c}-0.15(1.46) \\
{[-0.42]}\end{array}$ & $\begin{array}{c}0.68(3.17)^{* *} \\
{[0.41]}\end{array}$ & $\begin{array}{c}-0.48(2.36)^{* *} \\
{[-0.61]}\end{array}$ & $\begin{array}{c}-0.10(1.34) \\
{[-0.44]}\end{array}$ \\
\hline Working part time & $\begin{array}{c}0.21(3.15)^{* *} \\
{[0.50]}\end{array}$ & $\begin{array}{c}0.02(0.12) \\
{[0.01]}\end{array}$ & $\begin{array}{c}-0.10(0.99) \\
{[-0.20]}\end{array}$ & $\begin{array}{c}0.76(16.69)^{* *} \\
{[3.58]}\end{array}$ \\
\hline On leave & $\begin{array}{l}0.18(0.26) \\
\quad[1.73]\end{array}$ & $\begin{array}{l}1.30(1.21) \\
{[1.02]}\end{array}$ & $\begin{array}{c}-36.2(167.2)^{* *} \\
{[-46.60]}\end{array}$ & $\begin{array}{c}1.22(4.36)^{* *} \\
{[8.05]}\end{array}$ \\
\hline Female & $\begin{array}{c}0.01(0.23) \\
{[0.05]}\end{array}$ & $\begin{array}{c}-0.07(0.55) \\
{[-0.04]}\end{array}$ & $\begin{array}{c}-0.17(2.12)^{* *} \\
{[-0.21]}\end{array}$ & $\begin{array}{c}-0.11(2.55)^{* *} \\
{[-0.51]}\end{array}$ \\
\hline Number of children in school age & $\begin{array}{c}0.05(1.96)^{* *} \\
{[0.17]}\end{array}$ & $\begin{array}{c}0.02(0.24) \\
{[0.02]}\end{array}$ & $\begin{array}{c}-0.19(3.59)^{* *} \\
{[-0.24]}\end{array}$ & $\begin{array}{c}-0.12(5.37)^{* *} \\
{[-0.57]}\end{array}$ \\
\hline Number of children beyond 6 years & $\begin{array}{c}0.06(1.06) \\
{[0.17]}\end{array}$ & $\begin{array}{c}-0.08(0.73) \\
{[-0.05]}\end{array}$ & $\begin{array}{c}-0.04(0.59) \\
{[-0.06]}\end{array}$ & $\begin{array}{l}0.04(1.02) \\
{[0.19]}\end{array}$ \\
\hline Age & $\begin{array}{c}-0.03(5.49)^{* *} \\
{[-0.08]}\end{array}$ & $\begin{array}{c}-0.09(8.61)^{* *} \\
{[-0.05]}\end{array}$ & $\begin{array}{c}-0.08(11.53)^{* *} \\
{[-0.10]}\end{array}$ & $\begin{array}{c}-0.02(4.61)^{* *} \\
{[-0.08]}\end{array}$ \\
\hline Logarithm to salary & $\begin{array}{c}0.72(1.69)^{*} \\
{[2.38]}\end{array}$ & $\begin{array}{c}1.97(2.17)^{* *} \\
{[1.22]}\end{array}$ & $\begin{array}{c}0.05(0.09) \\
{[0.16]}\end{array}$ & $\begin{array}{c}-2.18(5.98)^{* *} \\
{[-10.53]}\end{array}$ \\
\hline 4 years of higher education & $\begin{array}{c}-0.32(2.09)^{* *} \\
{[-0.90]}\end{array}$ & $\begin{array}{c}-0.15(0.47) \\
{[-0.10]}\end{array}$ & $\begin{array}{c}0.24(1.11) \\
{[0.35]}\end{array}$ & $\begin{array}{c}-0.42(4.86)^{* *} \\
{[-1.96]}\end{array}$ \\
\hline 5 years of higher education & $\begin{array}{c}-0.28(1.65)^{*} \\
{[-0.76]}\end{array}$ & $\begin{array}{c}0.16(0.46) \\
{[0.11]}\end{array}$ & $\begin{array}{c}0.25(1.08) \\
{[0.36]}\end{array}$ & $\begin{array}{c}-0.39(4.02)^{* *} \\
{[-1.83]}\end{array}$ \\
\hline 6 years of higher education & $\begin{array}{c}-0.29(1.47) \\
{[-0.87]}\end{array}$ & $\begin{array}{l}0.11(0.27) \\
{[0.06]}\end{array}$ & $\begin{array}{c}0.38(1.38) \\
{[0.49]}\end{array}$ & $\begin{array}{c}0.12(0.88) \\
{[0.59]}\end{array}$ \\
\hline \multicolumn{5}{|l|}{ Region characteristics } \\
\hline Unemployment rate & $\begin{array}{c}-0.68(-0.14) \\
{[-0.78]}\end{array}$ & $\begin{array}{c}-10.00(1.70)^{*} \\
{[-5.75]}\end{array}$ & $\begin{array}{c}-7.29(1.87)^{*} \\
{[-8.90]}\end{array}$ & $\begin{array}{c}-4.88(2.25)^{* *} \\
{[-22.4]}\end{array}$ \\
\hline Log of population & $\begin{array}{c}0.14(1.59) \\
{[0.43]}\end{array}$ & $\begin{array}{c}-0.39(3.91)^{* *} \\
{[-0.23]}\end{array}$ & $\begin{array}{c}-0.22(3.34)^{* *} \\
{[-0.28]}\end{array}$ & $\begin{array}{c}-0.04(0.94) \\
{[-0.19]}\end{array}$ \\
\hline $\begin{array}{l}\text { The share of people living in rural } \\
\text { areas }\end{array}$ & $\begin{array}{c}-1.37(3.32)^{* *} \\
{[-3.90]}\end{array}$ & $\begin{array}{c}-0.62(1.46) \\
{[-0.34]}\end{array}$ & $\begin{array}{c}-0.31(1.03) \\
{[-0.33]}\end{array}$ & $\begin{array}{c}-0.11(0.53) \\
\quad[-0.28]\end{array}$ \\
\hline The share of divorced people between & $3.94(0.90)$ & $-0.60(0.11)$ & $6.50(1.67)^{*}$ & $1.93(0.76)^{*}$ \\
\hline $\begin{array}{l}16 \text { and } 66 \text { years } \\
\text { The share of immigrants }\end{array}$ & $\begin{array}{c}{[10.93]} \\
-5.96(1.44)\end{array}$ & $\begin{array}{c}{[-0.54]} \\
-0.96(0.20)\end{array}$ & $\begin{array}{c}{[8.07]} \\
1.10(0.34)\end{array}$ & $\begin{array}{c}{[8.17]} \\
1.25(0.66)\end{array}$ \\
\hline & {$[-17.56]$} & {$[-0.50]$} & {$[1.57]$} & {$[6.79]$} \\
\hline Predicted probability & 0.03 & 0.006 & 0.013 & 0.05 \\
\hline
\end{tabular}

Note. 60485 observations. The model is estimated by the multinomial logit method. Asymptotic t-values in parentheses, calculated based on standard errors corrected to account for within-school clustering of errors, and marginal effects in percentage points in brackets. * and ** denotes significance at ten and five percent level respectively. In addition to the reported variables, the variables reported in Table 4, labor market region specific effects and year specific effects are included in the model. 


\section{CESifo Working Paper Series}

(for full list see www.cesifo-group.de)

1405 Luisa Fuster, Ayşe İmrohoroğlu and Selahattin İmrohoroğlu, Personal Security Accounts and Mandatory Annuitization in a Dynastic Framework, February 2005

1406 Peter Claeys, Policy Mix and Debt Sustainability: Evidence from Fiscal Policy Rules, February 2005

1407 James M. Malcomson, Supplier Discretion over Provision: Theory and an Application to Medical Care, February 2005

1408 Thorvaldur Gylfason, Interview with Assar Lindbeck, February 2005

1409 Christian Gollier, Some Aspects of the Economics of Catastrophe Risk Insurance, February 2005

1410 Gebhard Kirchgässner, The Weak Rationality Principle in Economics, February 2005

1411 Carlos José Fonseca Marinheiro, Has the Stability and Growth Pact Stabilised? Evidence from a Panel of 12 European Countries and Some Implications for the Reform of the Pact, February 2005

1412 Petter Osmundsen, Frank Asche, Bård Misund and Klaus Mohn, Valuation of International Oil Companies -The RoACE Era, February 2005

1413 Gil S. Epstein and Shmuel Nitzan, Lobbying and Compromise, February 2005

1414 Marcel F. M. Canoy, Jan C. van Ours and Frederick van der Ploeg, The Economics of Books, February 2005

1415 Eric A. Hanushek and Ludger Wößmann, Does Educational Tracking Affect Performance and Inequality? Differences-in-Differences Evidence across Countries, February 2005

1416 George Kapetanios and M. Hashem Pesaran, Alternative Approaches to Estimation and Inference in Large Multifactor Panels: Small Sample Results with an Application to Modelling of Asset Returns, February 2005

1417 Samuel Mühlemann, Jürg Schweri, Rainer Winkelmann and Stefan C. Wolter, A Structural Model of Demand for Apprentices. February 2005

1418 Giorgio Brunello and Lorenzo Rocco, Educational Standards in Private and Public Schools, February 2005

1419 Alex Bryson, Lorenzo Cappellari and Claudio Lucifora, Why so Unhappy? The Effects of Unionisation on Job Satisfaction, March 2005 
1420 Annalisa Luporini, Relative Performance Evaluation in a Multi-Plant Firm, March 2005

1421 Giorgio Bellettini and Carlotta Berti Ceroni, When the Union Hurts the Workers: A Positive Analysis of Immigration Policy, March 2005

1422 Pieter Gautier, Michael Svarer and Coen Teulings, Marriage and the City, March 2005

1423 Ingrid Ott and Stephen J. Turnovsky, Excludable and Non-Excludable Public Inputs: Consequences for Economic Growth, March 2005

1424 Frederick van der Ploeg, Back to Keynes?, March 2005

1425 Stephane Dees, Filippo di Mauro, M. Hashem Pesaran and L. Vanessa Smith, Exploring the International Linkages of the Euro Area: a Global VAR Analysis, March 2005

1426 Hans Pitlik, Friedrich Schneider and Harald Strotmann, Legislative Malapportionment and the Politicization of Germany's Intergovernmental Transfer System, March 2005

1427 Konstantinos Angelopoulos and Apostolis Philippopoulos, The Role of Government in Anti-Social Redistributive Activities, March 2005

1428 Ansgar Belke and Daniel Gros, Asymmetries in the Trans-Atlantic Monetary Policy Relationship: Does the ECB follow the Fed?, March 2005

1429 Sören Blomquist and Luca Micheletto, Optimal Redistributive Taxation when Government's and Agents' Preferences Differ, March 2005

1430 Olof Åslund and Peter Fredriksson, Ethnic Enclaves and Welfare Cultures - QuasiExperimental Evidence, March 2005

1431 Paul De Grauwe, Roberto Dieci and Marianna Grimaldi, Fundamental and NonFundamental Equilibria in the Foreign Exchange Market. A Behavioural Finance Framework, March 2005

1432 Peter Egger, Stefan Gruber, Mario Larch and Michael Pfaffermayr, Knowledge-Capital Meets New Economic Geography, March 2005

1433 George Economides and Apostolis Philippopoulos, Should Green Governments Give Priority to Environmental Policies over Growth-Enhancing Policies?, March 2005

1434 George W. Evans and Seppo Honkapohja, An Interview with Thomas J. Sargent, March 2005

1435 Helge Berger and Volker Nitsch, Zooming Out: The Trade Effect of the Euro in Historical Perspective, March 2005

1436 Marc-Andreas Muendler, Rational Information Choice in Financial Market Equilibrium, March 2005 
1437 Martin Kolmar and Volker Meier, Intra-Generational Externalities and InterGenerational Transfers, March 2005

1438 M. Hashem Pesaran and Takashi Yamagata, Testing Slope Homogeneity in Large Panels, March 2005

1439 Gjermund Nese and Odd Rune Straume, Industry Concentration and Strategic Trade Policy in Successive Oligopoly, April 2005

1440 Tomer Blumkin and Efraim Sadka, A Case for Taxing Education, April 2005

1441 John Whalley, Globalization and Values, April 2005

1442 Denise L. Mauzerall, Babar Sultan, Namsoug Kim and David F. Bradford, Charging $\mathrm{NO}_{x}$ Emitters for Health Damages: An Exploratory Analysis, April 2005

1443 Britta Hamburg, Mathias Hoffmann and Joachim Keller, Consumption, Wealth and Business Cycles in Germany, April 2005

1444 Kohei Daido and Hideshi Itoh, The Pygmalion Effect: An Agency Model with Reference Dependent Preferences, April 2005

1445 John Whalley, Rationality, Irrationality and Economic Cognition, April 2005

1446 Henning Bohn, The Sustainability of Fiscal Policy in the United States, April 2005

1447 Torben M. Andersen, Is there a Role for an Active Fiscal Stabilization Policy? April 2005

1448 Hans Gersbach and Hans Haller, Bargaining Power and Equilibrium Consumption, April 2005

1449 Jerome L. Stein, The Transition Economies: A NATREX Evaluation of Research, April 2005

1450 Raymond Riezman, John Whalley and Shunming Zhang, Metrics Capturing the Degree to which Individual Economies are Globalized, April 2005

1451 Romain Ranciere, Aaron Tornell and Frank Westermann, Systemic Crises and Growth, April 2005

1452 Plutarchos Sakellaris and Focco W. Vijselaar, Capital Quality Improvement and the Sources of Growth in the Euro Area, April 2005

1453 Kevin Milligan and Michael Smart, Regional Grants as Pork Barrel Politics, April 2005

1454 Panu Poutvaara and Andreas Wagener, To Draft or not to Draft? Efficiency, Generational Incidence, and Political Economy of Military Conscription, April 2005 
1455 Maurice Kugler and Hillel Rapoport, Skilled Emigration, Business Networks and Foreign Direct Investment, April 2005

1456 Yin-Wong Cheung and Eiji Fujii, Cross-Country Relative Price Volatility: Effects of Market Structure, April 2005

1457 Margarita Katsimi and Thomas Moutos, Inequality and Relative Reliance on Tariffs: Theory and Evidence, April 2005

1458 Monika Bütler, Olivia Huguenin and Federica Teppa, Why Forcing People to Save for Retirement may Backfire, April 2005

1459 Jos Jansen, The Effects of Disclosure Regulation of an Innovative Firm, April 2005

1460 Helge Bennmarker, Kenneth Carling and Bertil Holmlund, Do Benefit Hikes Damage Job Finding? Evidence from Swedish Unemployment Insurance Reforms, May 2005

1461 Steffen Huck, Kai A. Konrad and Wieland Müller, Merger without Cost Advantages, May 2005

1462 Louis Eeckhoudt and Harris Schlesinger, Putting Risk in its Proper Place, May 2005

1463 Hui Huang, John Whalley and Shunming Zhang, Trade Liberalization in a Joint Spatial Inter-Temporal Trade Model, May 2005

1464 Mikael Priks, Optimal Rent Extraction in Pre-Industrial England and France - Default Risk and Monitoring Costs, May 2005

1465 François Ortalo-Magné and Sven Rady, Heterogeneity within Communities: A Stochastic Model with Tenure Choice, May 2005

1466 Jukka Pirttilä and Sanna Tenhunen, Pawns and Queens Revisited: Public Provision of Private Goods when Individuals make Mistakes, May 2005

1467 Ernst Fehr, Susanne Kremhelmer and Klaus M. Schmidt, Fairness and the Optimal Allocation of Ownership Rights, May 2005

1468 Bruno S. Frey, Knight Fever - Towards an Economics of Awards, May 2005

1469 Torberg Falch and Marte Rønning, The Influence of Student Achievement on Teacher Turnover, May 2005 